\title{
Scalp vein sign: a forgotten clinical clue?
}

\author{
Shriraam Mahadevan, ${ }^{1,2}$ Adlyne Reena Asirvatham, ${ }^{3}$ Subramanian Kannan, ${ }^{4}$ \\ Dhalapathy Sadacharan ${ }^{5,6}$
}

${ }^{1}$ Endocrinology Department, Sri Ramachandra Medical College, Chennai, India

${ }^{2}$ Endocrinology, Endocrine \& Speciality Clinic, Chennai, India ${ }^{3}$ Sri Ramachandra University Medical College, Chennai, India ${ }^{4}$ Endocrinology, Diabetes and Bariatric Medicine, Narayana Health City, Bengaluru, India ${ }^{5}$ Endocrine Surgery, Madras Medical College, Chennai, India ${ }^{6}$ Department of Endocrine Surgery, Endocrine and Speciality Clinic, Chennai, India

\section{Correspondence to} Dr Shriraam Mahadevan, mshriraam@gmail.com

Accepted 3 April 2017

\section{CrossMark}

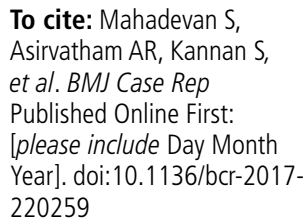

\section{DESCRIPTION}

A 72-year-old man presented for general health check. He was asymptomatic except for hard of hearing and uses hearing aid for the last 4 years. Clinical examination revealed very prominent tortuous superficial temporal veins bilaterally, more on the left side (figure 1) with no bruit and a warm non-tender skull on palpation. Serum chemistries showed significantly elevated alkaline phosphatase $1520 \mathrm{U} / \mathrm{L}$ (normal, 45-140 U/L) with normal liver, kidney and haematological parameters. Serum calcium, phosphorus, 25-hydroxy vitamin D and parathyroid hormone levels were normal. Skull radiograph showed moth-eaten appearance suggestive of Pagetoid bone (figure 2). With this clinico-biochemical picture in an otherwise asymptomatic individual, Paget's disease of bone was strongly considered. It was confirmed by significant uptake of technetium-methylene diphosphonate (MDP) in skull and right hemipelvis. He was managed with intravenous zoledronic acid, calcium and vitamin D supplementation. Serum alkaline phosphatase normalised at 6 months follow-up, though hearing and scalp vein distension did not improve significantly. Paget's disease of bone, hitherto considered to be rare, is now being increasingly diagnosed in India. ${ }^{1}$ Skull involvement is commonly seen in polyostotic

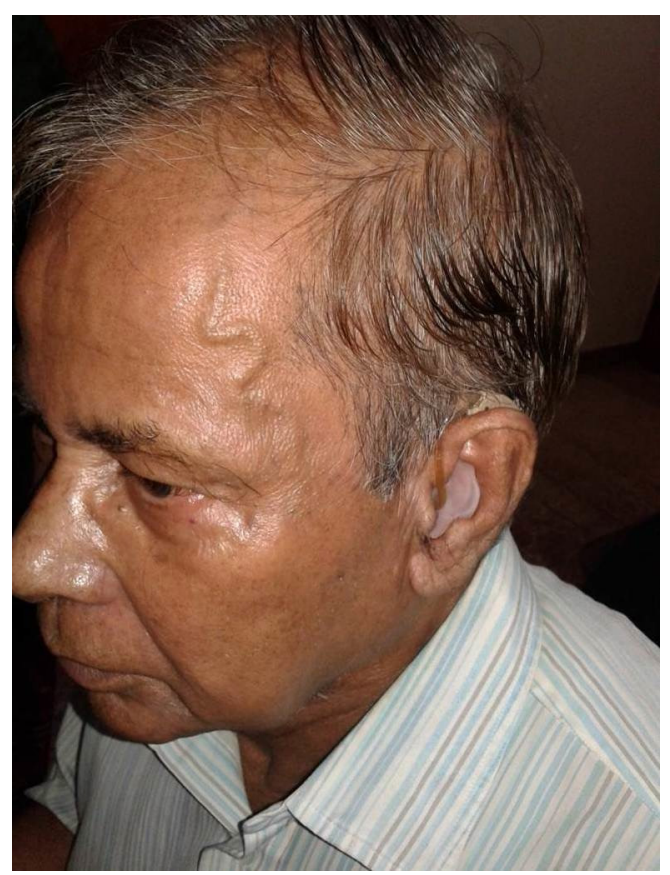

Figure 1 Clinical picture showing prominent, tortuous, left superficial temporal vein with hearing aid.

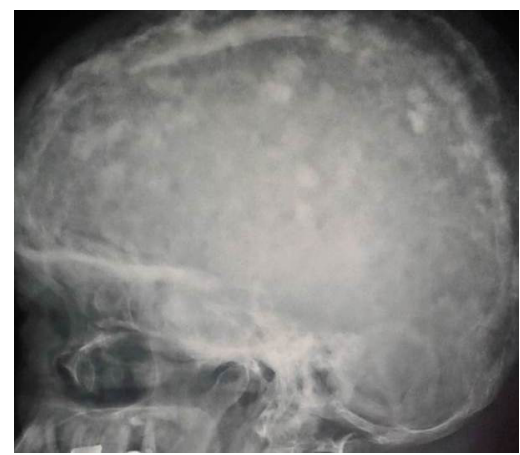

Figure 2 Lateral view of skull radiograph showing the typical 'moth-eaten' appearance of Pagetoid bone.

Paget's disease. Prominent superficial temporal vein which occurs due to increased vascularity and arteriovenous shunting was earlier described as 'Scalp vein sign'. ${ }^{2}$ In a case series of 290 patients, this sign was observed in $45 \%$ of those with skull involvement ${ }^{3}$ and hence may serve as a useful clinical clue in asymptomatic individuals. Conditions which could mimic this sign include giant cell arteritis and metastases of follicular thyroid carcinoma, wherein the arteries become more prominent and tender.

\section{Learning points}

- Paget's disease of bone is not uncommon in South India.

- Skull involvement is very common in polyostotic Paget's disease.

- Prominent superficial temporal vein is a simple clinical sign that along with raised alkaline phosphatase may aid in diagnosis of asymptomatic Paget's disease of bone.

Contributors SM was involved in the diagnosis and management of the patient, literature search and preparation of the manuscript. ARA was involved in the diagnosis, literature search and manuscript review. SK was Involved in patient diagnosis and critical review of the manuscript. DS was involved in manuscript review and critical comments.

Competing interests None declared.

Patient consent Obtained.

Provenance and peer review Not commissioned; externally peer reviewed.

(c) BMJ Publishing Group Ltd (unless otherwise stated in the text of the article) 2017. All rights reserved. No commercial use is permitted unless otherwise expressly granted.

\section{REFERENCES}

1 Anjali S, Thomas N, Rajaratnam S, et al. Paget's disease of bone: experience from a centre in southern India. J Assoc Physicians India 2006;54:525-9. 


\section{Images in...}

2 Altman RD, Gray RG. Scalp vein sign in Paget's disease of bone. J Rheumatol 1982;9:624-6.

3 Altman RD. Musculoskeletal manifestations of Paget's disease of bone. Arthritis Rheum 1980:23:1121-7.

Copyright 2017 BMJ Publishing Group. All rights reserved. For permission to reuse any of this content visit

http://group.bmj.com/group/rights-licensing/permissions.

BMJ Case Report Fellows may re-use this article for personal use and teaching without any further permission.

Become a Fellow of BMJ Case Reports today and you can:

- Submit as many cases as you like

- Enjoy fast sympathetic peer review and rapid publication of accepted articles

- Access all the published articles

- Re-use any of the published material for personal use and teaching without further permission

For information on Institutional Fellowships contact consortiasales@bmjgroup.com

Visit casereports.bmj.com for more articles like this and to become a Fellow 